\title{
27 \\ MILITARIZATION AND IMPUNITY IN SRI LANKA
}

\author{
Øivind Fuglerud
}

In this chapter, I will review some political developments unfolding in Sri Lanka since the presidential election in November 2019 that brought Gotabaya Rajapaksa to power. Focusing on the increasingly important role in public administration given to officers of the armed forces, I will review these developments against the backdrop of the country's long history of systematic human rights violations and a context of politically endorsed impunity for such violations. I argue that the 2019 presidential election represents a change towards autocracy in that military circles close to the president, supported by an ideology of ethnic majoritarianism, now openly assert control over civil government functions by way of presidential authority delegated to them. Let me begin with a brief contextualizing snapshot:

On 14 May 2020, the Sri Lankan secretary of defence and the two chiefs of the Sri Lankan army and navy paid an official visit to two archaeological sites, Muhudu Maha Vihara and Digavapi, both old Buddhist temples. Two of the three men, secretary of defence general (Rtd.) Kamal Gunaratne and commander of the army general Shavendra Silva, are widely known to the public as incarnations of the military might that in 2009 crushed the Liberation Tigers of Tamil Eelam (LTTE) and tens of thousands of Tamil civilians with it (see UN 2011: 41, also OHCHR 2015). By international human rights organizations, they are pointed to as war criminals (ITJP and JfD 2020; HRW 2021). In the words of the prominent Sri Lankan political commentator Dr. Dayan Jayatilleka who watched the news item on TV, the dignitaries arrived in a

long convoy of glossy black four-wheel drives coming down a dusty road with a heat haze shimmering in the background. Elite guards in red berets and body-armor, sunshades and carrying Heckler-and-Koch MP6s dismount, escorting the Bosses, also in shades, one in civvies and tie, the others in uniform.

(Jayatilleka 2020a)

Both Muhudu Maha Vihara and Digavapi are located in the southern part of the Eastern Province where the three major ethnic communities in Sri Lanka - the Sinhalese, the Tamils, and the Muslims - live in close proximity and compete for resources. Access to the two sites and the use of the land surrounding them have for more than 60 years been contested by local ethnic communities, as indeed has the surrounding area in a more general sense (Manogaran 
1994; Nuhman 2016). The visit came about due to complaints of Muslim destruction of temple ruins considered sacred by Sinhalese Buddhists, presented to the president himself by the leaders of the Buddhist order, the Sangha. Having supported Gotabaya Rajapaksa's election campaign, they presented the complaint during the first monthly meeting of the Buddhist Advisory Council established by the new president. In the second meeting, following the military leadership's excursion, the president decided to entrust the survey and preservation of archaeological sites in the Eastern Province to a presidential task force headed by the defence secretary. Despite the complex demography of the Eastern Province, all members of the task force appointed by the president are Sinhalese (Gazette Extraordinary No. 2178/17). The president also decided to establish a separate naval military sub-unit to maintain the security in the environs of the Muhudu Maha Vihara (Balachandran 2020).

Spokespersons for the Tamil and Muslim communities in Sri Lanka claim that consecutive governments for decades have used archaeological findings as a pretext to mark locations as Buddhist sites in order to promote 'Sinhalization' of areas traditionally dominated by minority settlements (Tamil Guardian 2020a; see also Oakland Institute 2021). One connection between the visit on 14 May 2020 and the theme of this chapter lies in the fact that the visit and the establishment of the naval unit to protect the Muhudu Maha Vihara shows that the military now has become a 'first responder' in civic disputes between the ethnic communities in the country (Jayatilleka 2020a). The message to the public conveyed by the media coverage of the event, and by giving the leadership of the presidential archaeological task force to the defence secretary, is that complaints brought forward by the Buddhist Advisory Council may now be rectified by military means. As pointed out by Jayatilleka, where one in a democratic country would expect the police to investigate complaints, or civil state institutions to find balanced solutions or settle disputed claims by the rule of law, the "current official discourse assumes that the matter is open-and-shut, and that the military arm of the state shall intervene on one side' (Jayatilleka 2020a). Jayatilleka, Sri Lanka's permanent representative to the United Nations in Geneva at the war's end in 2009, former ambassador to France and Russia, has repeatedly warned against the recently elected president's 'openly Sinhala-Buddhist supremacist line' (Jayatilleka 2020b) and the possibility of 'a fanatical Sinhala-Buddhist military rule' led by him (Jayatilleka 2018).

\section{A new role for the armed forces}

Providing a more prominent position to the military has been on top of the political agenda of the new president, who was secretary of defence between 2005 and 2015. In his election manifesto (Rajapaksa undated [2019]: 13), Gotabaya Rajapaksa pointed to the fact that under the previous government, in power between 2015 and 2019, 'personnel in our intelligence agencies, armed forces and the police have been subjected to humiliation, victimization, intimidation and imprisonment, which has resulted in a collapse of morale', a situation he promised to rectify if elected. Similarly, his brother, prime minister Mahinda Rajapaksa, president from 2005 until 2015, has argued that 'members of the intelligence services were persecuted, harassed, and jailed by the previous government on false charges' (Times online 2019). The 'false charges' referred to are allegations of war crimes brought forward in several reports by the UN, but also allegations of corruption, torture, kidnappings and extrajudicial murders not directly related to the war.

The human rights situation in Sri Lanka in general and the conduct of the Sri Lankan army during the last phase of the civil war in particular, has been an issue in the UN's Human Rights Council since the war ended in 2009. In March 2014 the Human Rights Council requested 


\section{Øivind Fuglerud}

the High Commissioner for Human Rights to "undertake a comprehensive investigation into alleged serious violations and abuses of human rights and related crimes by both parties in Sri Lanka', and 'to establish the facts and circumstances of such alleged violations and of the crimes perpetrated with a view to avoiding impunity and ensuring accountability' (Human Rights Council 2014: 4). This request mandated the investigation resulting in the report from the Office of the High Commissioner for Human Rights Investigation on Sri Lanka (OISL, see OHCHR 2015), which was tabled in the Human Rights Council in 2015 and was followed by Human Rights Council Resolution 30/1 (Human Rights Council 2015). Mahinda Rajapaksa saw the fact that the joint SLFP - UNP government that came to power after he lost the presidential election to Maithripala Sirisena in 2015 supported Resolution 30/1 as a direct affront to himself and his government as victors in the war against the LTTE. Consequently, this support was soon withdrawn after his brother Gotabya Rajapaksa was elected president and appointed Mahinda prime minister. One central proposal in Resolution 30/1 was the establishment of 'a judicial mechanism ... to investigate allegations of violations and abuses of human rights and violations of international humanitarian law' in which members 'of Commonwealth and other foreign judges, defence lawyers and authorized prosecutors and investigators' were to participate (Human Rights Council 2015: 4). Resolution 30/1 is cast as a follow-up to the OISL-report, which among its many observations concluded that:

... there are reasonable grounds to believe the Sri Lankan security forces and paramilitary groups associated with them were implicated in unlawful killings carried out in a widespread manner against civilians and other protected persons during the period covered by OISL's report.

(OHCHR 2015: 219, para 1116)

This is a very different version of what happened during the last phase of the civil war from Mahinda Rajapaksa's, who in 2010 claimed that Sri Lanka's military had won the war 'carrying a gun in one hand and the Declaration of Human Rights in the other' (Rajapaksa 2010).

During the first six to seven months of his presidency, Gotabaya Rajapaksa and his brother and appointed prime minister took a number of steps to provide the armed forces a new role in the governance of the country. One of their first political decisions was to establish a special presidential commission mandated to inquire into and collect information on investigative agencies falsely accusing public officers of criminal activities (Gazette Extraordinary No. 2157/44 \& No. 2159/16). This 'Commission of Inquiry to Investigate Allegations of Political Victimization During the Period Commencing 08th January 2015 and Ending 16th November 2019' was given broad powers, and immediately used its authority to order the attorney general's department not to proceed with several cases against politicians and security personnel pending in court. After the commission delivered its report in three volumes in early 2021, the president established another presidential commission to implement the recommendations of the former (Gazette Extraordinary No. 2212/53). This commission is authorized to recommend the imposition of civic disability on persons found guilty of political victimization, thereby bypassing established judicial institutions and mechanisms (CPA 2021a). According to Sri Lanka's Imposition of Civic Disabilities (Special Provisions) Act, 'civic disability' disqualifies a person from voting at elections; from being a candidate at elections; for membership of any local authority; for membership of Parliament; and for employment as a public servant. If subject to the imposition of civic disability, a person would therefore also need to vacate his or her Parliamentary seat, leave any public position, or terminate employment as a public servant. 
One case the commission on political victimization tried but failed to close down was the legal proceedings against fourteen naval officers for the abduction, torture, extortion and conspiracy to murder of eleven persons in 2008 and 2009, among them one child and six students. Among the 14 accused were one former chief of defence staff and one former commander of the navy and advisor to the president on national security. The victims, none of them with any record of terrorist activity, were allegedly kidnapped in Colombo for ransom, after which they were taken to the Trincomalee naval base where they were later murdered (for a presentation of the case, see ITJP 2019b). In this particular case, the attorney general withstood the pressure from the presidential commission and scheduled new court hearings. However, in June 2020 proceedings were stayed by the court of appeal, raising doubts about the political independence of the judiciary. In April 2021, the prime minister tabled a resolution in Parliament seeking the acquittal of the accused and withdrawal of the indictment, as well as recommending that investigators and witnesses are charged under the Penal Code and Bribery Act for fabricating evidence. If accepted by Parliament such a Resolution would mean overriding the judicial process, in violation of the principles of the separation of powers and the rule of law in a constitutional democracy (CPA 2021b). On 4 August 2021, the Sri Lankan Attorney General's Department decided not to proceed with charges against former Navy commander Wasantha Karannagoda in the case (Amnesty International 2021).

Sensing which way the wind was blowing, Inspector Nishanthi Silva in the Criminal Investigation Department (CID), who in the 2015 - 2019 interregnum investigated a number of high-profile cases involving members of the Rajapakasa regime and security personnel associated with them, soon after the presidential election fled the country, seeking asylum in Switzerland (Colombo Telegraph 2019). One of the cases in his portfolio had been the murder in 2009 of Lasantha Wickrematunge, founding editor of The Sunday Leader and influential critic of the Mahinda Rajapaksa government. When murdered, Wickrematunge's newspaper was digging into a case of corruption involving the then defence secretary, and, reportedly, CID officer Silva had in an open court hearing pointed to Gotabaya Rajapaksa as the person responsible for the murder (Chandraprema 2018). Following Silva's escape, the government removed the director of the CID who had backed the investigations, and relegated him to a menial job in the southern part of the country. He was later imprisoned, accused of fabricating evidence against a police officer who had worked closely with Gotabaya Rajapaksa during his time as defence secretary. This police officer was in 2015 sentenced to death for murder. The will of the new president to uphold his campaign pledge 'to release war heroes languishing in prison over false charges and cases' (Rajapaksa undated [2019]) was proven by his pardoning in March 2020 of former staff sergeant Sunil Ratnayake who was convicted in 2015 for the murder of eight Tamil civilians, including three children, in Mirusuvil in April 2000. The conviction of Ratnayake, which was upheld by the Supreme Court only a few months before the pardon, is one of the very few exceptions to full impunity for military personnel in Sri Lanka for whatever crimes committed against members of the minorities.

In terms of public administration, a large number of civilian government services were soon after the instatement of the new president brought under the control of the Ministry of Defence, including the National Media Centre, the Secretariat for Non-Governmental Organizations, and the Telecommunication Regulatory Authority. This was part of a larger centralizing operation concentrating power in the hands of the president and the prime minister (News First 2019). Between 25 January and 2 June 2020, the president established seven different presidential task forces, several of them led by military officers. Common to all are their broad and vague powers, and the fact that they circumvent the accountability of Sri Lanka's Parliamentary 
democracy by operating outside government ministries' normal chain of command. Several of the task forces' fields of responsibility overlap with that of civilian agencies.

Especially worrying was the establishment in June 2020 of the 'Presidential Task Force to build a Secure Country, Disciplined, Virtuous and Lawful Society' (Gazette Extraordinary No. 2178/18). This, like the archaeological task force mentioned above, is led by the secretary of defence. It includes among its members the commanders of the Sri Lanka army, navy and air force, chief of the National Intelligence Service, director of State Intelligence Service, and the directors of the army-, navy- and air force intelligence units. The task force has sweeping powers and reports directly to the president. It is mandated to take 'necessary immediate steps to curb the illegal activities of social groups which are violating the law which is emerging as harmful to the free and peaceful existence of society at present', and 'to investigate and issue directions as may be necessary' on all matters within its broad and vague mandate. A number of civil society organizations in Sri Lanka have questioned the legality of the task forces within the constitution of Sri Lanka (e.g. CPA 2020) and have construed the powers given to them as a step in the direction of authoritarianism and military dictatorship (Sri Lanka Campaign for Peace and Justice 2020; Friday Forum 2020).

In installing his military-dominated regime, the new president was helped by the Covid-19 pandemic. When the pandemic struck in March 2020, the president's response was to give the overall responsibility for fighting the disease to general Shavendra Silva, commander of the Sri Lankan Army. In preparation for a general election in April, the president dissolved Parliament with effect from 2 March. However, due to the pandemic, the election was postponed until 5 August, and the Parliament remained dissolved for five months, two more months than the constitution allows. This made organized opposition to presidential rule difficult. A full two months nation-wide 'corona-curfew' dampened political debate further. News agencies reported the official number of arrested for breaking the curfew to be more than 60,000 (Xinhua 2020; Tamil Guardian 2020b), providing rich opportunity also to clamp down on criticism. Thirtytwo trade unions, press freedom organizations and civil society groups in a joint statement noted in April 2020 that 'it appears, under the guise of the suppression of Covid-19 epidemic the government is suppressing the right of people to express their views and their right to protest' (Sri Lanka Brief 2020). In a joint statement published in late July 2020, ten international human- and civil-rights organizations, including Amnesty International, Human Rights Watch and the International Commission of Jurists, pointed out that since the presidential election a campaign of fear has intensified. 'Dissident voices and critics of the current government, including lawyers, journalists, human rights defenders and victims of past abuses, are being targeted by the police, intelligence agencies and pro-government media', the statement noted (Amnesty International 2020a).

With effect from January 2021, the president appointed 25 military officers, a majority with combat experience from the last phase of the war, as 'chief coordinating officers' to all districts to manage operations to control the spread of the coronavirus (ITJP and JfD 2021). While at the time of writing, the picture is not clear, according to one source the authority of the chief coordinating officers extends well beyond Covid-19 and includes coordinating economic revival, poverty alleviation, disaster management, and even overseeing police operations (Lanka e-News 2021).

\section{Militarization and disappearances}

The new role of the military in Sri Lanka's political landscape and the sabotaging of judicial investigations of security personnel and politicians are recent additions to a much larger picture 
emerging over time. I will briefly discuss two aspects of this picture here, militarization and human rights violations:

Sri Lanka's social fabric has since the late 1970s been gradually transformed by a process of militarization in the sense described by Cyntia Enloe (2000: 291) as a 'step-by-step process by which something becomes controlled by, dependent on, or derives its value from the military as an institution or militaristic criteria'. Militarization is a multi-stranded socio-political process through which certain assumptions, values, and beliefs are rooted in society. Among the core ideas of militarism are the conceptions that armed force is the ultimate resolver of tensions, and that hierarchical relations and lines of command produce the most effective action.

One dimension of militarization in Sri Lanka is the securitization of territories and communities. Throughout the civil war, the Tamil population in the conflict-affected areas were presented as a threat to the state that could be dealt with only through military means. The extended use of emergency powers and anti-terrorism legislation to govern during difficult times, has led to a state of exception remaining even after the state of emergency ceased to exist (Satkunanathan 2015: 374-375). Several reports by international human rights organizations have told of continued surveillance, arbitrary arrests, and torture in the former war-zone long after the threat to the state represented by the LTTE was eradicated in 2009 (e.g. ITJP 2015; HRW 2018). In 2017, one study found that in Mullaithivu, the district where the last phase of the war was fought, there was, eight years after the war ended, at least one army soldier for every two civilian residents (Adayalaam Centre for Policy Research \& PEARL 2017).

Another dimension of militarization consists of what Venugopal (2011) calls 'military fiscalism', in which state expenditure through the security apparatus has established a lifeline to impoverished and otherwise neglected rural areas. By the 1990s, the Sri Lankan army had become the single largest employer in the country, and that with a salary level of almost double what salaried private sector jobs pay. In the five districts focused on in Venugopal's analysis, more than half of Sinhala Buddhist men between 18 and 30 in cash employment work in some branch of the military. In many of the poorest villages, almost every household has at least one member with either a salary, a pension, or some other financial bond to the military. The political support mobilized through these linkages is one probable reason for the counter-intuitive rise in the number of soldiers recruited after the end of the war in 2009. According to World Bank data, the number of Sri Lankan armed forces personnel grew from 223,100 in 2009 to 317,000 in 2017 (Macrotrends 2020). With this rise in numbers has come the encroachment of the military into almost every corner of civilian life from the production and retail of food to tourism, philanthropic undertakings, and leadership training for school principals and university students.

Impunity for human rights violations committed by the country's security forces has plagued Sri Lanka for many decades (for a discussion of legal provisions see International Commission of Jurists 2012). Since the 1970s, international and domestic human- and civil-rights organizations have continuously reported on abductions and unlawful killings committed by members of the country's security apparatus and militias associated with them. Many of the victims were never found. In its preliminary observations at the conclusion of its visit to Sri Lanka in 2015, the UN Working Group on Enforced or Involuntary Disappearances observed that enforced disappearances have been used in Sri Lanka in a massive and systematic way. It also noted that both 'during and after the war enforced disappearances were even used for purely economic extortion purposes by some State officials and affiliated paramilitaries' (WGEID 2015). In 2016 the leader of the government's Office on National Unity and Reconciliation, former president Chandrika Bandaranaike Kumaratunga, acknowledged that Sri Lankan governments had received at least 65,000 complaints of disappearances since 1994 (Reuters 2016). Amnesty 
International observes that Sri Lanka has one of the world's highest number of disappearances, 'with between 60,000 and 100,000 people vanishing since the late 1980s' (Amnesty International 2020b).

\section{Impunity and alliances}

Enforced disappearances and military impunity in Sri Lanka are outcomes of irregular or non-institutional alliances between politicians, the military, and non-state armed groups. Such alliances became particularly noticeable during the suppression of the Sinhalese Maoist movement Janatha Vimukthi Peramuna ('People's Liberation Front'), JVP for short. This movement, which developed independently of the armed Tamil groups in the northern and eastern parts of the country, staged two rebellions against the Sri Lankan state, the first in 1971 and the second from 1987 onwards. By the end of 1988, Sri Lanka's South was close to anarchy; roads were blocked, supply of electricity sabotaged, telephone lines cut, public services closed down. Then, from 1989, the security forces changed their strategy and increasingly fought JVP with their own brutal methods. Death squads with pompous names became part of everyday life: 'Black Cats', 'Yellow Cats', 'Eagles of the Central Highlands', 'People's Revolutionary Red Army' (PRRA); masked men in civilian clothes, cars without number plates passing unhindered through security checkpoints, bodies with signs of torture burning on the roadside.

Central to these groups were networks of soldiers and intelligence officers operating apart from the formal chain of command, many of them personally marked by JVP's violence. The exact number of persons killed during the second uprising is unknown. Amnesty International suggests 'perhaps 30,000', and mentions in its report that the government at the time attributed to the JVP a total of 6,517 killings between 1987 and mid-March 1990 (Amnesty International 1990: 13). Politicians judging the brutal methods necessary backed those on the frontline, sometimes with private grudges thrown in. Inside sources have claimed that planned liquidations of JVP-members and their families were based on lists drawn up by powerful politicians and local dignitaries, some of them using the opportunity to solve private disagreements and animosities (Amnesty International 1990). After the war against the JVP was won, the methods developed were put to use in the war against the LTTE, prominent among them the use of irregular armed groups coordinated by military officers.

For understanding the present-day situation in Sri Lanka, it is significant that the current president himself and several of his close military associates cut their teeth in the fight against the JVP in the late 1980s. Current secretary of defence Kamal Gunaratna and army commander Shavendra Silva both served under president Gotabaya Rajapaksa during his time as commander of the Gajaba Regiment. The Gajaba regiment's place of posting in 1989 was Matale, where Gotabaya Rajapaksa was the security-coordinating officer until the end of the JVP insurrection. In Matale a mass grave with the remains of at least 154 people with signs of torture was discovered in 2013, believed by local forensic experts to be victims of the government's fight against the JVP. However, before conclusive evidence could be collected, the investigation was taken away from the judiciary and handed over to a commission established by Gotabaya Rajapaksa's president brother Mahinda Rajapaksa. In 2015, the commission concluded that the findings were not related to the JVP period (see ITJP 2019a). The two mentioned officers serving under Gotabaya Rajapaksa in the Gajaba Regiment went on to become among the most central military commanders during the end-fight against the LTTE, both of them subsequently pointed to as suspected war criminals by international human rights organizations (ITJP and JfD 2020; HRW 2021). Instead of being investigated, they were after the conclusion 
of the war generously rewarded with military promotions and diplomatic or political postings, as were many of their colleagues also mentioned in the reports.

After the election of Mahinda Rajapaksa for president and the appointment of Gotabaya Rajapaksa as secretary of defence in 2005 , the collective trauma left by the death squads of the late 1980s was reactivated. The phenomenon of 'white van abductions', the kidnapping by unknown groups travelling in unmarked white vans, commonly assumed to consist of operators with links to the armed forces, soon reached new heights. By September 2006, the human rights group University Teachers for Human Rights (UTHR (J)) reported between three and eight killings per day in Jaffna. 'Killer units of the state go about in white vans and with masks on motorcycles and are by now unconcerned about hiding their affiliations', they noted (UTHR (J) 2006). A new trait now was that many abductions took place in areas controlled by the government, including Colombo. Many of those made to disappear from these areas had no discernible links to the LTTE (Jeyaraj 2016).

Unsurprisingly, the exact nature of who and what when it comes to disappearances and unlawful killings is shrouded in darkness. What is known is that the rise in numbers occurred at the same time as the security forces, under Gotabaya Rajapaksa's leadership, were increasingly making use of the services of Tamil militants at war with the LTTE. This relationship between the armed forces and Tamil militias was as such not new. In the North, the militia of Eelam People's Democratic Party (EPDP), at odds with the LTTE from the beginning of the civil war, had had a working relationship with the military for a long time. Now, after breaking away from the LTTE in 2004 the remaining forces of LTTE's former commander in the Eastern Province, Vinayagamoorthy Muralitharan aka 'colonel' Karuna Amman, operating under the name of Tamil Makkal Viduthalai Pulikal (TMVP), became the 'running dogs' of the military intelligence (Jeyaraj 2016). The two militias of EPDP and TMVP now competed for the delivery of irregular military services to the army in the government-controlled part of the country. While initially commissioned to undermine LTTE's networks and influence, their activity soon degenerated into profit-seeking crime. International Crisis Group points out that the reliance on paramilitaries to fight the government's war while refusing to pay them for it blurred the lines between political and criminal violence (ICG 2007: 11). They also point to the existence of 'hybrid groups', military intelligence cadres and Tamil paramilitaries operating together, resulting in a dissolving of institutional command structures and lack of accountability. The UN OISL report (OHCHR 2015: 81-94, see also HRW 2007) confirms this general picture.

Seen against this backdrop accusations made by field marshal Sarath Fonseka, former commander of the Sri Lankan Army, are interesting. In 2017, he claimed that the former defence secretary - the current president - personally supervised all security and intelligence operations in and around Colombo through a separate chain of command made up of loyalists, bypassing the normal organizational structures of the three -armed forces and the police. 'It is through this group', Fonseka stated on TV, that 'the Rajapaksas put together a faction to plan high profile assaults, abductions and murders of media personalities and others, under the auspices of the targets being a threat to national security' (Sri Lanka Brief 2017). After coming back to power in 2019, the president and prime minister have not forgotten their old Tamil paramilitary associates. Douglas Devananda, leader of EPDP, is a cabinet minister; the ex-LTTE commander Karuna Amman was in October 2020 appointed as district coordinator of prime minister Mahinda Rajapaksa for Batticaloa and Ampara in the Eastern Province (The Island 2020). His former deputy, Sivanesathurai Chandrakanthan aka 'Pillayan', was elected to Parliament in the 2020 election while in remand prison suspected of murder. As the sole elected representative of TMVP Chandrakanthan is currently part of the president's $2 / 3$ majority in Parliament. In January 2021, the murder case against him was dropped (Adaderana 2021). 
As indicated above, there is a continuity in human rights violations in Sri Lanka from the suppression of the second JVP rebellion of the late 1980s until today, both in terms of methods and in terms of individual organizers in the security apparatus (ITJP and JfD 2020). Currently, many of these organizers are filling political positions around the president and the prime minister.

\section{Concluding discussion}

What is unfolding in Sri Lanka after the presidential election in November 2019 is a qualitatively new development in the direction of autocratic rule. What appears is a democratically backsliding state in the shape of a hybrid between 'the garrison society' (Dibble 1966-67) and 'the oligarchic-corporate state' (Kapferer 2005). Dibble's concept 'garrison society' emphasizes the coalescence of different social spheres under the dominance of the military; that is the social embeddedness of military force, rationality, and knowledge. Characteristic of a garrison society is a situation where institutions and elites holding military, economic, and political power have become dependent upon one another; in which their goals and interests are complementary (Dibble ibid.: 106). In Sri Lanka, this development comes with a twist. Through their personalized control over state functions, and their alliances with business interests and the armed forces, the Rajapaksa clan between 2005 and 2015 provided the Sri Lankan state formation an increasingly 'oligarchic-corporate' character (Kapferer 2005). What this label denotes is rule by a body, a corporation, organized on the basis of personal association, patterns of patronal distribution, and loyalty to a leading family, coming together to pursue common interests, in this case power and profit. With the two Rajapaksa brothers back in power, this development has now entered a new and more militarized phase, consolidating a foundation of personal political-military alliances for dynastic rule.

Following the August 2020 Parliamentary election, which provided their party SLPP and its allies a comfortable 2/3 majority, allowing them to pass in Parliament amendments to the constitution considerably strengthening the executive branch of government, the new cabinet that was established included president Gotabaya and prime minister Mahinda Rajapaksa's elder brother Chamal and Mahinda's eldest son Namal Rajapaksa. In July 2021 the younger brother of the president and the prime minister, Basil Rajapaksa, often considered the family's main strategist, was added to the list of cabinet ministers. Between them, the five family members currently hold nine ministerial posts, including minister of defence and minister of finance. Basil Rajapaksa also chairs the powerful Presidential Task Force for Economic Revival and Poverty Alleviation, bringing together under his authority a broad range of actors drawn from the sectors of public security, government regulation, banking, and private enterprise. Again, this task force reports directly to the president.

With universal franchise being implemented in 1931, Sri Lanka (Ceylon) is considered Asia's oldest democracy. While bruised and battered by two Maoist uprisings and a long civil war the democratic structure still stands, if only barely. To what extent it will survive the structural changes in governance ushered in by the post-2019 regime remains to be seen.

\section{Bibliography}

Adaderana. 2021. 'AG to drop murder case against Pillayan'. News item posted 11 January 2021. www.adaderana.lk/news.php?nid=70671, last accessed 10 January 2021.

Adayaalam Centre for Policy Research \& PEARL. 2017. Normalising the Abnormal: The Militarisation of Mullaitivu. Report from Adayaalam Centre for Policy Research and People for Equality and Relief 
in Lanka. http://adayaalam.org/wp-content/uploads/2018/01/Normalising-the-Abnormal-TheMilitarisation-of-Mullaitivu.pdf, last accessed 15 March 2021.

Amnesty International. 1990. Sri Lanka. Extrajudicial executions, 'disappearances' and torture, 1987 to 1990. AI Index: ASA 37/21/90.

Amnesty International. 2020a. 'Sri Lanka: Human Rights Under Attack. Lawyers, Human Rights Defenders and Journalists Arrested, Threatened, Intimidated'. Joint press release. www.amnesty.org/ download/Documents/ASA3728022020ENGLISH.pdf, last accessed 9 September 2020.

Amnesty International. 2020b. Enforced Disappearances. Sri Lanka. Amnesty International, What we do. www.amnesty.org/en/what-we-do/disappearances/, last accessed 9 September 2020.

Amnesty International. 2021. 'Sri Lanka: Authorities falter on accountability in 'Navy 11' case'. Press release 4 August 2021. amnesty.org/en/latest/news/2021/08/sri-lanka-authorities-falter-onaccountability-in-navy-11-case/, last accessed 3 September 2021

Balachandran, P.K. 2020. 'Why Rajapaksa Has Brought Archaeology Preservation Under His Defence Secretary', The Citizen 26 May 2020. www.thecitizen.in/index.php/en/NewsDetail/index/6/ 18792/Why-Rajapaksa-Has-Brought-Archaeology-Preservation-Under-His-Defence-Secretary-, last accessed 27 May 2020.

Chandraprema, C. A. 2018. 'Quest to implicate Gota in Lasantha's murder'. Lankaweb, posted 17 March 2018. www.lankaweb.com/news/items/2018/03/17/quest-to-implicate-gota-in-lasanthas-murder/, last accessed 5 October 2020.

Colombo Telegraph. 2019. 'CID Inspector of Police Nishantha Silva has fled the country after receiving death threats, Colombo Telegraph can reveal'. News item posted 24 November 2019. www.colombotelegraph.com/index.php/nishantha-flees-country/, last accessed 15 March 2021

CPA. 2020. The Appointment of the two presidential task forces. Discussion Paper, Centre for Policy Alternatives. www.cpalanka.org/wp-content/uploads/2020/06/Commentary-Two-Task-Forces-CPA-Final.pdf, last accessed 17 June 2020.

CPA. 2021a. 'Initial Concerns with the Report of the Commission of Inquiry to Investigate Allegations of Political Victimization and Subsequent Action'. Press release 12 March 2021. www.cpalanka.org/initialconcerns-with-the-report-of-the-commission-of-inquiry-to-investigate-allegations-of-politicalvictimization-and-subsequent-action/, last accessed 15 March 2021.

CPA. 2021b. 'Short Note on the Resolution Seeking Parliamentary Approval to Implement the Recommendations of the CoI on Political Victimization'. Press release 19 April 2021. www. cpalanka.org/short-note-on-the-resolution-seeking-Parliamentary-approval-to-implement-therecommendations-of-the-coi-on-political-victimization/, last accessed 7 May 2021.

Dibble, Vernon K. 1966-67. 'The Garrison Society'. New University Thought, Vol. 5, No. 1 \& 2 , pp. 106-115.

Enloe, Cyntia. 2000. Maneuvers: The International Politics of Militarizing Women's Lives. Berkeley, Los Angeles and London: University of California Press.

Friday Forum. 2020. 'The Rule of Law and Democratic Governance'. Media Release, 11 June 2020. https://srilankabrief.org/2020/06/sri-lanka-friday-forum-calls-on-all-democratic-forces-to-urgethe-president-to-withdraw-the-military-task-force/, last accessed 17 June 2020.

HRW. 2007. Complicit in Crime - State Collusion in Abductions and Child Recruitment by the Karuna Group, Human Rights Watch, Vol. 19, No. 1 (c), 2007.

HRW. 2018. Locked Up Without Evidence Abuses under Sri Lanka's Prevention of Terrorism Act. Human Rights Watch. Report published January 2018.

HRW. 2021. 'Sri Lanka's UN Efforts to Stave Off Justice for War Crimes'. Human Rights Watch Commentary by Brad Adams, Asia Director 3 February. www.hrw.org/news/2021/02/03/ sri-lankas-un-efforts-stave-justice-war-crimes

Human Rights Council. 2014. 25/1. Promoting reconciliation, accountability and human rights in Sri Lanka. Resolution adopted by the Human Rights Council on 26 March 2014.

Human Rights Council. 2015. 30/1. Promoting reconciliation, accountability and human rights in Sri Lanka. Resolution adopted by the Human Rights Council on 1 October 2015.

ICG. 2007. Sri Lanka's Human Rights Crisis. International Crisis Group Asia Report No. 135. ICG.

International Commission of Jurists. 2012. Authority without accountability: The crisis of impunity in Sri Lanka. Geneva: ICJ. www.icj.org/sri-lanka-new-icj-report-documents-crisis-of-impunity/, last accessed 12 January 2021.

ITJP. 2015. A Still Unfinished War: Sri Lanka's Survivors of Torture and Sexual Violence 2009-2015. International Truth and Justice Project. https://itjpsl.com/assets/stoptorture_report_v4_online.pdf\#english, last accessed 15 March 2021. 


\section{Øivind Fuglerud}

ITJP. 2019a. Shavendra Silva Chief of Army Staff Sri Lanka. Dossier. International Truth and Justice Project, 29 January 2019. https://itjpsl.com/assets/shavendra-Silva_-final-dossier.pdf, last accessed 4 July 2020.

ITJP. 2019b. The Sri Lankan Navy. A Collective Blind Eye. International Truth and Justice Project October 2019. https://itjpsl.com/assets/press/ITJP_navy_reportfinal-2-SINGLES.pdf, last accessed 6 October 2020.

ITJP and JfD. 2020. 'Continuing Crimes - Matale to Mullivaikkal'. International Truth and Justice Project and Journalists for Democracy in Sri Lanka Joint Press Release 14 December 2020. https://itjpsl.com/ assets/press/Final-OMP-Press-release-4-December-2020-copy.pdf, last accessed 07 January 2021.

ITJP and JfD. 2021. 'Sri Lanka's COVID Military Overlords'. International Truth and Justice Project and Journalists for Democracy in Sri Lanka Joint Press Release 6 January 2021. https://itjpsl.com/assets/ press/Final-ITJP-JDS-press-release-6-January-2021.pdf, last accessed 07 January 2021.

Jayatilleka, Dayan. 2018. 'End of Civility, Barracks: Model of Politics and Millennium's Children'. Daily Mirror, 18 July 2018. www.dailymirror.lk/article/END-OF-CIVILITY-BARRACKS-MODEL-OFPOLITICS-AND-MILLENNIUM-S-CHILDREN-152839.html, last accessed 12 January 2021.

Jayatilleka, Dayan. 2020a. 'Defence re-defined: The military as first resort'. FT Daily, Lanka Guardian Column, Thursday May 21. www.ft.lk/columns/Defence-re-defined-The-military-as-first-resort/4700510, last accessed 28 May 2020.

Jayatilleka, Dayan. 2020b. 'MR 2020: Elections and legacy'. FT Daily, Lanka Guardian Column, Thursday 4 June. www.ft.lk/columns/MR-2020-Elections-and-legacy/4-701137, last accessed 9 June 2020.

Jeyaraj, D.B.S. 2016. " "White-Vanning Culture" and the Lucrative Industry of Abducting Tamils for Ransom'. DBSJeyaraj.com, posted 26 August 2016. http://dbsjeyaraj.com/dbsj/archives/47804, last accessed 5 October 2020

Kapferer, Bruce. 2005. 'Introduction: Oligarchic Corporations and New State Formations', Social Analysis: The International Journal of Anthropology, Vol. 49, No. 1 (Spring 2005), pp. 163-176.

Lanka e-News. 2021. 'The country is reaching a turning point in militarization..! Colonels above Government Agents..!' News item posted 3 January 2021. www.lankaenews.com/news/3315/en, last accessed 06 January 2021

Macrotrends. 2020. 'Sri Lanka Military Size 1985-2020'. www.macrotrends.net/countries/LKA/srilanka/military-army-size, last accessed 02 November 2020.

Manogaran, Chelvadurai. 1994. 'Colonization as Politics: Political Use of Space in Sri Lanka's Ethnic Conflict'. In Chelvadurai Manogaran and Bryan Pfaffenberger (eds.), The Sri Lankan Tamils. Ethnicity and Identity, pp. 84-125. New York: Routledge.

News First. 2019. 'Defence Ministry vested with key institutions including TRCSL, DMC and CERT'. News item posted 11 December 2019. www.newsfirst.lk/2019/12/11/defence-ministry-vested-withkey-institutions-including-trcsl-dmc-and-cert/, last accessed 15 March 2021.

Nuhman, M.A. 2016. 'Sinhala Buddhist Nationalism and Muslim Identity in Sri Lanka: One Hundred Years of Conflict and Coexistence'. In John Clifford Holt (ed.), Buddhist Extremists and Muslim Minorities: Religious Conflict in Contemporary Sri Lanka, pp. 18-53. Oxford: Oxford University Press.

Oakland Institute. 2021. Endless War. The Destroyed Land, Life, and Identity of the Tamil People in Sri Lanka. www.oaklandinstitute.org/tamils-sri-lanka-endless-war, last accessed 15 March 2021.

OHCHR. 2015. Report of the OHCHR Investigation on Sri Lanka (OISL), Advance Version. A/HRC/30/ CRP.2, United Nations High Commissioner for Human Rights.

Rajapaksa, Gotabaya. Undated [2019]. Gotabaya presents to you a Reconstructed Country with a Future. Vistas of Prosperity and Splendour. Election manifesto, publisher not provided.

Rajapaksae, Mahinda. 2010. Our Armed Forces Battled Carrying Gun in One Hand and the Declaration of Human Rights the Other. Full Text of President Mahinda Rajapaksae's Address at the 'Victory Day' Celebrations at Galle Face, Colombo, 18 June 2010. Transcurrents. http://transcurrents.com/tc/ 2010/06/our_armed_forces_battled_carry.html, last accessed 12 November 2011.

Reuters. 2016. 'Sri Lanka admits 65,000 missing from war, insurrection'. News item posted 8 June 2016. https://in.reuters.com/article/sri-lanka-rights/sri-lanka-admits-65000-missing-from-warinsurrection-idINKCNOYU277, last accessed 7 October 2020.

Satkunanathan, Ambika. 2015. 'The Executive and the Shadow State in Sri Lanka'. In A. Welikala (ed.), Reforming Sri Lankan Presidentialism: Provenance, Problems and Prospects, pp. 371-398. Colombo: Centre for Policy Alternatives.

Sri Lanka Brief. 2017. 'Sri Lanka: Probe Into Lasantha's Murder Takes A Twist'. https://srilankabrief.org/ 2017/01/sri-lanka-probe-into-lasanthas-murder-takes-a-twist/, last accessed 4 October 2020. 
Sri Lanka Brief. 2020. 'Sri Lanka Brief Up Date - 16 April 2020. Covid-19 Pandemic \& Freedom of Expression Rights'. https://srilankabrief.org/2020/04/sri-lanka-brief-up-date-16-april-2020-covid19-pandemic-freedom-of-expression-rights/, last accessed 9 September 2020.

Sri Lanka Campaign for Peace and Justice. 2020. 'Sri Lanka's slide into authoritarianism', press release 10 June 2020. www.srilankacampaign.org/sri-lankas-slide-into-authoritarianism/, last accessed 18 June 2020.

Tamil Guardian. 2020a. 'All Sinhala task force for Sri Lanka's 'archaeology' in East'. News item posted 03 June 2020. www.tamilguardian.com/content/all-sinhala-task-force-sri-lanka\%E2\%80\%99s\%E2\%80\%98archaeology\%E2\%80\%99-east, last accessed 15 March 2021.

Tamil Guardian. 2020b. 'Over 60,000 arrested in Sri Lanka for violating COVID-19 curfew'. News item posted 23 May 2020. www.tamilguardian.com/content/over-60000-arrested-sri-lanka-violatingcovid-19-curfew, last accessed 15 March 2021.

The Island. 2020. 'Karuna Amman appointed district coordinator of Prime Minister'. News item posted 15 October 2020. https://island.lk/karuna-amman-appointed-district-coordinator-of-prime-minister/, last accessed 11 January 2021.

Times online. 2019. 'PM Rajapaksa pledges to rectify injustices suffered by Armed forces under previous Govt'. News item posted 13 December 2019. www.sundaytimes.lk/article/1112134/pmrajapaksa-pledges-to-rectify-injustices-suffered-by-armed-forces-under-previous-govt, last accessed 10 June 2020.

UN. 2011. Report of the Secretary-General's Panel of Experts on Accountability in Sri Lanka. 31 March 2011. www.securitycouncilreport.org/un-documents/document/poc-rep-on-account-in-sri-lanka.php, last accessed 25 February 2021.

University Teachers for Human Rights (Jaffna). 2006. The Wider Implications of the Human Rights and Humanitarian Crisis in Jaffna. UTHR(J) Information Bulletin no. 41, 14 September 2006.

Venugopal, R. 2011. 'The Politics of Market Reform at a Time of Civil War: Military Fiscalism in Sri Lanka'. Economic and Political Weekly 46 (49): 67-75.

WGEID. 2015. Preliminary observations of the Working Group on Enforced or Involuntary Disappearances at the conclusion of its visit to Sri Lanka (9-18 November 2015). www.ohchr.org/EN/NewsEvents/Pages/ DisplayNews.aspx?NewsID=16771\&LangID=E, last accessed 10 July 2020.

Xinhua. 2020. 'Over 60,000 arrested in Sri Lanka for violating COVID-19 curfew'. News item posted 20 May 2020. www.xinhuanet.com/english/2020-05/20/c_139072700.htm, last accessed 9 September 2020. 